\title{
Impact of Population Growth on Unemployment in Nigeria: Dynamic OLS Approach
}

\author{
MAIJAMA'A Rabiu \\ NNPC Retail Sales Representative Bauchi, Nigerian National Petroleum Corporative, Central \\ Business District, NNPC Tower, Abuja-Nigeria \\ MUSA Kabiru Saidu, \\ Department of Economics, Faculty of Social and Management Sciences, Bauchi State University, Gadau, P.M.B \\ 065, Yuli Campus, Bauchi State, Nigeria \\ YAKUBU Muktari \\ Department of Economics, Faculty of Social and Management Sciences, Bauchi State \\ University, Gadau, P.M.B 065, Yuli Campus, Bauchi State, Nigeria \\ MOHAMMED Nafisa \\ Central Bank of Nigeria (CBN), Gombe Branch, Gombe State -Nigeria
}

\begin{abstract}
This empirical research examined the impact of population growth on unemployment in Nigeria. The study applied annual time series data from 1991 to 2017. The data on population, unemployment, consumer price index, exchange rate and foreign direct investment were tested for unit root using ADF, PP and KPSS unit root tests. The results from the ADF and PP tests revealed that all the variables were stationary at first difference except CPI that is stationary at level. While the KPSS units root test result shows that all the variables are stationary at level. The variables were co-integrated as shown by the Johansen Juselius test for co-integration. The Dynamic Ordinary Least Squares (DOLS) were used in the process of estimating the model. The main results disclosed that population and exchange rate impacted positively with unemployment. Whereas consumer price index, GDP per capita and foreign direct investment impacted negatively thereby reducing the rate of unemployment in the long-run. Government should focus more on attracting foreign direct investment, increasing GDP per capita and the desired rate of consumer price index in order to control the rate of unemployment in the country.

Keywords: Population Growth, Unemployment, Dynamic Ordinary Least Squares, Co-integration test, GDP per capita, Consumer Price Index, Foreign Direct Investment.
\end{abstract}

DOI: $10.7176 / \mathrm{JESD} / 10-22-09$

Publication date: November $30^{\text {th }} 2019$

\section{Introduction}

After the independence in 1960, a successful population census was carried out in Nigeria in 1964, which an estimated population of 55.6 million people was taken into account. Since then, it becomes obvious that Nigeria's population was leading to a rapid population growth. In 1991, a population census was held and the country's population increased to an approximated 88.5 million people. The analysis helped the National Development Planning to gain more insight and enable them to improve and developed more on their policies and planning (Evans, 2011). The UNDP reported in 2007 that the Nigerian population continuously increased at 3\% per annum with birth rate of 40 per 1,000 and also death rate of 15 per 1,000 (Gideon, 2016). It was also estimated that an educated Nigerian woman gives birth to a lesser number of 3 children compared to an average Nigerian woman who gives birth to 6 children in life lifetime (Evans, 2011). From analysis of the past census and reports, it is evident that the population has been rapidly growing a high rate of $250 \%$ from 1964 to present. This makes it problematic to match the population growth rate and development of the country (Evans, 2011).

Nigeria at the present has the highest population in Africa and the $10^{\text {th }}$ in the world ranking. It was reported that the Nigerian population is associated with three factors namely; fertility, migration and mortality. It was noticed that the population growth increases at 3\% which implies a doubling time of 22 years (Evans, 2011). This also means that the country is growing at a geometric progression. The problem with this is the capacity of the country's economy to also grow proportionately that it will cope and accommodate the increased population. The low mortality of 14 per 1,000 decreased infant mortality rate and higher life expectancy signifies a problem because it indicates higher chance of survival (Evans, 2011).

The total population in Nigeria was estimated at 195.9 million people in 2018, according to the latest census figures. Looking back, in the year of 1960, Nigeria had a population of 45.1 million people (NBS, 2018). 


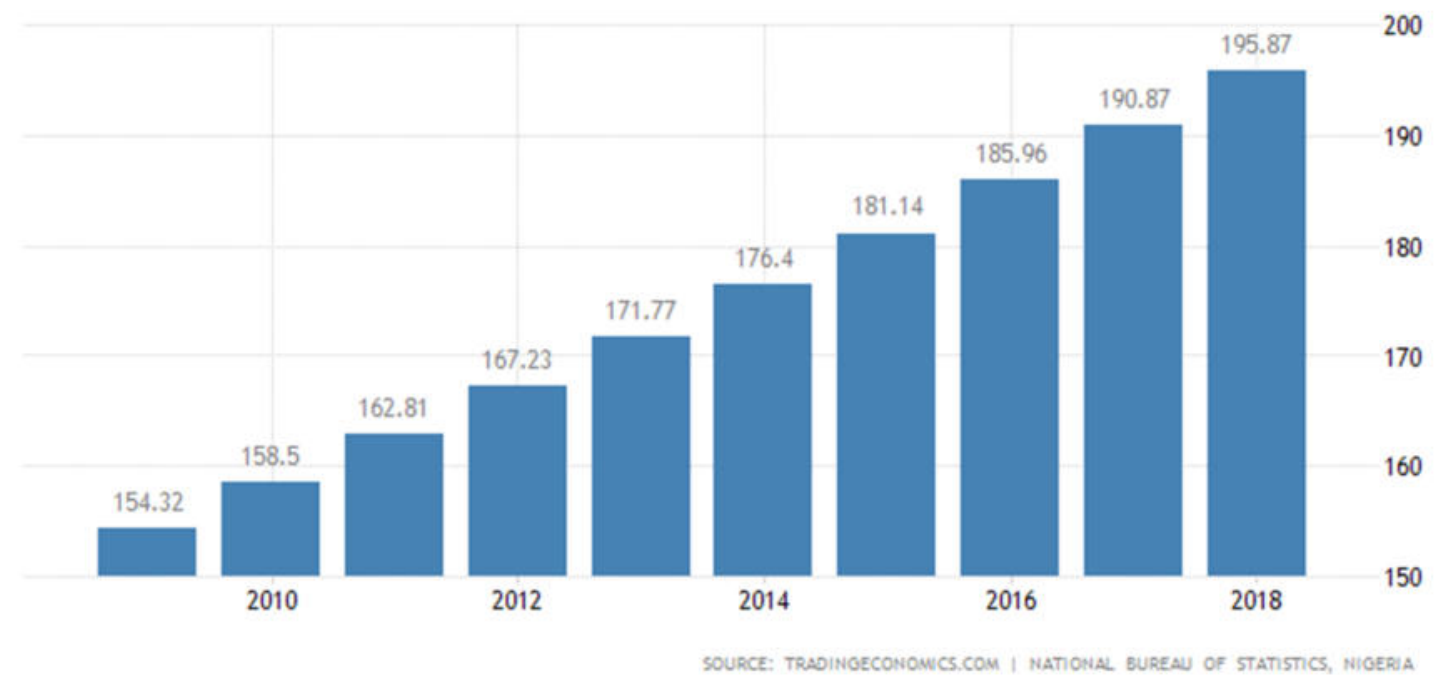

Figure 1: Nigeria's Population from 2010 to 2018.

The unemployment rate is undoubtedly the most widely cited labour market indicator by media and decisionmakers around the world (ILO, 2018). According to the latest ILO estimates, the global unemployment rate (the share of unemployed in the total labour force) stood at 5.6 percent in 2017 and has been in a long-term downward trend since 2009, when it hit 5.9 per cent (following a sudden increase from 5.5 in 2008 as a result of the global job crisis). This means that fewer than six out of every 100 persons in the labour force around the world are unemployed.

The unemployment rate conveys the percentage of persons in the labour force who do not have a job but are available and looking for one, where the labour force is the sum of employed persons and unemployed persons. The unemployment rate provides a good depiction of the extent to which people who are ready to work are actually able to find and start a job. In other words, it expresses the labour market's ability to satisfy people's explicit demand for jobs, which is certainly useful and valuable information, but as this brief will show, it is not enough to paint a full picture of the extent of labour underutilization and the overall state of the labour market. In fact, the unemployment rate focuses on a very specific population (the unemployed) and says nothing about the situation of persons in employment or about persons outside the labour force. Persons employed managed to escape unemployment. Labour underutilization refers to mismatches between labour supply and demand, leading to an unmet need for employment among the population. Unemployment is naturally at the core of labour underutilization (the unemployed are, after all, those with the clearest, most explicit unmet need for employment), and so, despite its limitations, the unemployment rate is often used as the sole measure of labour underutilization (ILO, 2018). Unemployment rate in Nigeria increased to 23.1 percent in the third quarter of 2018 from 22.70 percent in the second quarter of 2018. The unemployment rate in Nigeria averaged 12.31 percent from 2006 until 2018 reaching an all-time high 23.10 percent in the third quarter of 2018 and a record low of 5.10 percent in the fourth quarter of 2010 (NBS, 2018). 


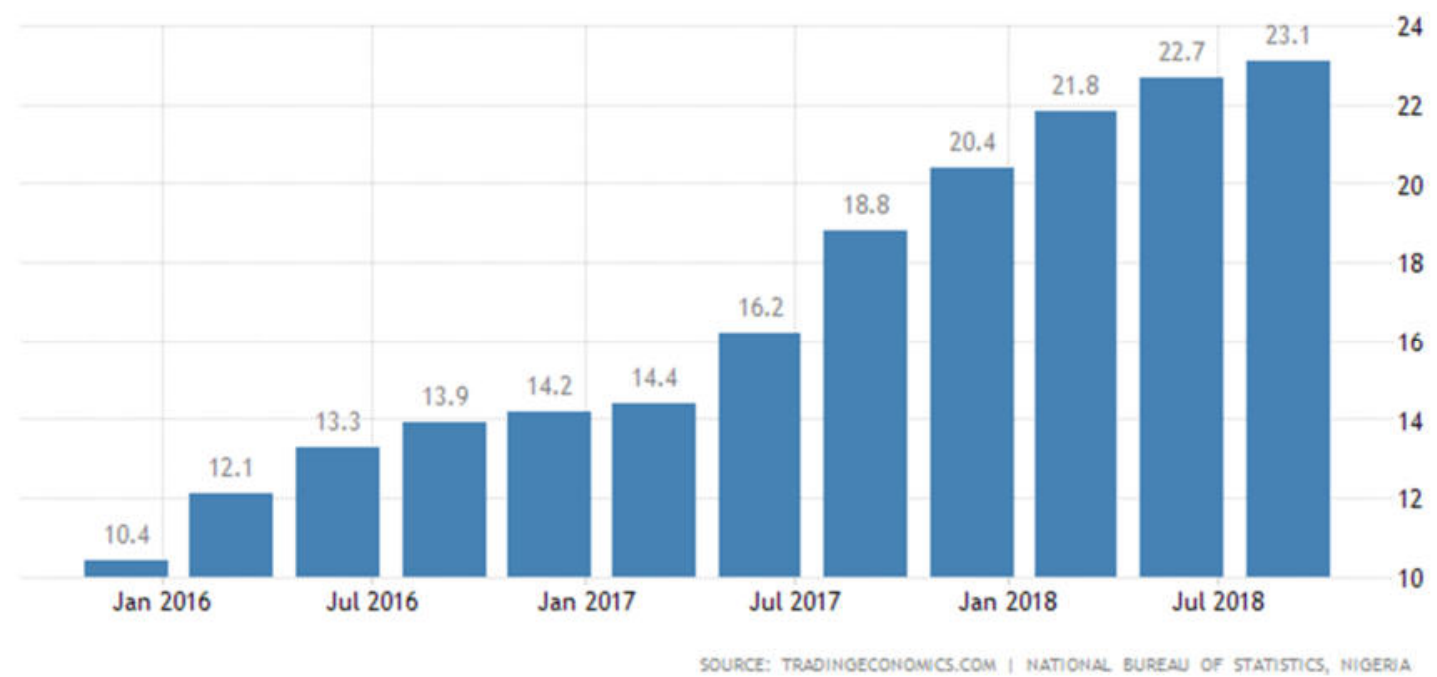

Figure 2: Nigeria's Unemployment rate from 2016 to 2018.

The research study is carried out to learn about the impact of population growth on unemployment problem in Nigeria, so as to find out the reason why the current rate of unemployment is high and increasing rapidly over the years. This will further give an understanding whether the high rate of unemployment is associated with the increasing population in the country. It has been obvious that over the years, the rate of population has been increasing at a geometric level and so does the unemployment rate, there seem to be a positive relationship existing among the two variables. If our hypothesis is true, then we will explore and research on the possible solutions that can best tackle the problem of unemployment and recommend policies which will tackle this problem which will in turn help in the growth and the development of our country Nigeria.

The significance of this research cannot be overemphasized. Firstly, it should help to inform the decision makers on the determinants of unemployment in Nigeria. Secondly, it provides policy recommendations that could assist in tackling the problem of unemployment in Nigeria. Equally, the empirical findings could further provide a hint on how population contributed to unemployment over the studied period. This research is of significant importance because it helps in addressing the crucial aspect of the economy. The country has been experiencing slow growth rate and a decline in development and unemployment is a negative indicator to economic development. Therefore, addressing this problem is of paramount importance as it will flush out major causes of unemployment and population growth. It will also suggest possible strategies and measures to be put in place to tackle the problem which will lead to the country's economic growth and attained eventual development.

The objective of this study was to look at the impact of population growth on unemployment in Nigeria. Many studies conducted in Nigeria to the best of our knowledge only looked at either the impact of unemployment rate and economic growth, Unemployment situation (Adekola, et al. 2016), population and its impact on the level of Unemployment (Ilegbinosa, et al. 2014), the impact of unemployment and inflation on economic growth (Ademola and Badiru, 2016), the effect of Unemployment rate and population growth rate on gross domestic product (Orume, 2016) and Unemployment and security challenges (Olubukola, 2013). Therefore, this study intended to fill the gap in the literature by studying the impact of population growth on unemployment in Nigeria. According to the literatures, population growth is supposed to have a direct relationship with unemployment given that the working population is growing (holding the factors effecting working population negatively) because an increase in population will means an increase in the supply of labour to the labour market thereby causing excess supply of labour over its demand and this facilitate persistent unemployment situation in the country, but only empirical tests could validate this. Accordingly, this study sought to empirically test the impact of population growth on unemployment situation in Nigeria by employing Dynamic Ordinary Least Squares (DOLS).

This article is organized in sections. The first section contains introduction, statement of research, significance of the study, objectives and organization of the article. The second section consists of review of related literature, which provides some snapshots of similar empirical literature. The third section presents methodology and data. The fourth section presents result and discussion of the findings. Finally, the fifth section discusses conclusion and policy recommendations.

Review of Related Literature

Many research studies have been conducted in areas related to this study. However, a major part of the researches conducted were either on unemployment-population growth and economic growth nexus, unemployment and 
security challenges, unemployment-inflation and economic growth nexus. Review of literature shows that there are no many existing studies that specifically examine the impact of population growth on unemployment situation in Nigeria. Though there is a bunch of literature that investigated the relationship between population growth and unemployment, the literature review here will give an overview of the existing literature on the evidence around the world and later narrow it down to focus on Nigeria. The first strand of the literature review will focus on evidence of related existing literatures around the world or general review of the related existing studies, whereas the second strand focuses specifically on the review of related existing research studies focusing on Nigeria.

Starting with the Bhally et al, (2013) analyzes the determinants of unemployment in Pakistan over a period of 1976 to 2012 using secondary data on unemployment, population, foreign direct investment, gross domestic product, inflation and external debt using ARDL. The results revealed that gross domestic product, population, inflation and foreign direct investment are significant determinants of unemployment in Pakistan in both the short run and long run periods.

Banda et al, (2016) analyzed the impact of economic growth on unemployment in South Africa using a secondary quarterly data on macroeconomic variables such as Unemployment rate, Gross domestic product, real effective exchange rate, Budget deficit and labour productivity for the periods spanning 1994 to 2012. The Johansen Juselius indicates the existence of long-run relationship among the variables. The Vector error correction model results indicate that gross domestic product, budget deficit and real effective exchange rate have positive long-run impact on unemployment while labour productivity is negatively related to unemployment. They authors recommend that South African government should redirect its spending towards activities that directly and indirectly promote creation of employment and decent jobs, a conducive environment and flexible labour market policies or legislations without impediments to employment creation should be created, and lastly government should prioritize industries that promote labour intensive.

Laku and Deda (2013) research on the situation of unemployment in relation to growth of population in Kosovo country. They present a real situation in Kosovo regarding labour policies, employment and the handle policies that are revealed to the labour market developments. Through tabular forms they present differences that are desperate where the most affected by unemployment are mostly young people. Urban and rural unemployment is increasing; its level is alarming to the younger generation and this is a serious threat to asocial and barrier development. Based on the demographic data until 2012 the country is being increased year by year. The same data show that over $60 \%$ of the population in Kosovo are the working age, therefore it is necessary an immediate intervention of governmental power through its arteries to alleviate the current situation because with the addition of population is increasing unemployment, an issue which must always stand inversely in relation with each other.

Mohsenia and Jouzaryan (2016) examined the role of inflation and unemployment on economic growth in Iran for the period of 1996 to 2012. The effect of inflation and unemployment on economic growth in the shortrun and long-run periods were investigated and examined using Autoregressive Distributed Lag (ARDL) Model. The Model estimation results showed the significant and negative effect of inflation and unemployment on economic growth in long - run, which indicated that inflation and unemployment decreased economic growth in long-run. This means that authorities should diligently endeavor plan to reduce, control inflation and unemployment. They recommend that the result will be useful to respected authorities in Iran, especially authorities of economic and social institutions in an attempt to reduce and control unemployment and inflation in order to achieve economic growth.

Imiosi et al, (2017) investigates the impact of unemployment on economic growth in Nigeria using Ordinary least squares multiple regression analytical method in analyzing annual secondary data on gross domestic product, unemployment rate, minimum wage, labour force and population for the period of 1980 to 2016 . The result reveal that unemployment, population and labour force have significant impact on the country's economic growth, while minimum wage rate does not have a significant impact on the country's economic growth. They researchers recommended that government should ensure that there is job creation in the economy especially in the real sector; private sector employers should be given subsidies so as to encourage them to employ more people; and the labour market should be regulated.

Adekola et al, (2016) investigates to prove whether unemployment is mainly caused by demographic change in Nigeria or there are other intrinsic factors responsible for this social challenge. A comparative analysis of the population and unemployment structure of three positively selected and heavily populated countries in the three different Continents-Nigeria, China and USA were undertaken. The results show that population growth is not the sole factor responsible for growing population, but the reverse is the case for Nigeria as both population and unemployment is growing.

Imiosi et al, (2014) in their study deals with the population and the problem of unemployment in LDCs. The economies of the LDCs are characterized by high population growth. They are facing great challenge in generating adequate job opportunities for their teeming population. Many facts and data from notable authors, agencies, websites and organizations were analyzed and discussed in the study regarding this problem. Nigeria is not left out as their population ever increases with limited number of job opportunities. The factors responsible for the increase 
in the level of unemployment in Nigeria includes: rural urban migration, wrong government policies, urban bias, lack of population control, lack of mental skill and practicability, corruption and Inspirited Entrepreneur drive. Reviewing the socio-economic organization, monitoring rural-urban migration, promoting agriculture and entrepreneurship programmes, Investment in human capital, and encouraging Public Private Partnership etc. were some of the recommendations made to avoid a "worst-case scenario" of the above problem and to realize the nation's vision as being one of the leading economies by the year 2020 .

Ademola and Badiru (2016) investigate and determine the effects of unemployment and inflation on economic performance in Nigeria using secondary data on real gross domestic product, unemployment and inflation rate for period spanning 1981 to 2014 . Co-integration relationship was established among the variables using Johansen Juselius test for co-integration and the OLS result shows that unemployment and inflation rate are positively related to economic growth. They recommended that government should embark on policy that will reduces the number of imported goods drastically and encourage local production and consumption to encourage domestic industries; these will reduce unemployment and inflation in Nigeria and increase output hence economic growth.

Orumie (2016) in his study applied the multiple regression models whose estimation co-integrates the inverse relationship between unemployment rate and gross domestic product considering population growth as well. Thus, providing opportunity to assessing other determinants of economic growth, (in this case, population growth). The results estimated by the model developed in this research study revealed that since 1970, the rate of unemployment and population has been on the increase amidst declining gross domestic product. The result also reveal that unemployment and population growth contribute commeasurably to gross domestic product. Furthermore, the result showed that unemployment contributes more to the national gross domestic product during this period in line with existing work.

Anuolam and Anuforo (2014) study the econometric examination of growth, unemployment and poverty in Nigeria using secondary data for the period of 1980 to 2010. A three stage least square (3SLS) estimate was used for the analysis and the results showed that poverty is negatively related to growth and agricultural production but positively related to unemployment rate, inflation rate, manufacturing and petroleum production. The economic growth is also found to be negatively related to poverty index and unemployment is positively related to poverty index and growth. They recommended the setting of an appropriate macroeconomic policies that will significantly reduce the high level of income inequalities which is crucial for poverty alleviation, people oriented growth policies and human capital development among others.

Anthony (2013) study youths' unemployment and crime in Nigeria. The phenomenon of crime has impacted negatively on the economic, social and political life of the nation over time. The youth population of any nation represents the driving force for development. However, for the youths to become useful resources, they must be gainfully employed. The youths are also the most volatile when their energies are misdirected or channeled into wrong endeavours. Available data show that youth employment is very rampant in Nigeria and this has contributed immensely to their involvement in criminal activities. The researcher argues that criminal activities such as armed robbery, kidnapping, political thuggery, militancy and other social vices found among the unemployed and jobless youths have contributed greatly to the slow pace of development in Nigeria. The study proffers that addressing youths' unemployment will stem the tide of crime and foster rapid development in Nigeria.

Chukwuma (2014) looked at the unemployment scourge in Nigeria. Data was collected from secondary source for the period of 2000 to 2011 and was analyzed with simple regression analysis and chi-square test. The study found out the unemployment rate is on the increase and does not depend on the level of education, age group and gender.

John and Bright (2012) examine the relationship between poverty and youth unemployment in Nigeria. The study employed secondary data for the period of 1987-2011 on incidence of poverty as a function of unemployment, agricultural, manufacturing and services contributions to real GDP, population and inflation rate in which the growth rate are analyzed using OLS. The results revealed that unemployment, agricultural and services contributions to real GDP as well as population have positive determining influence on poverty level in Nigeria with only agricultural sector statistically insignificant. While manufacturing sector contribution to real GDP and inflation rate exhibited negative relationship on poverty level in Nigeria with only manufacturing sector appearing significant. The study recommended among other things, that holistic effort should be made by governments at all levels to create jobs and arrest unemployment.

Ayoade and Agwu (2016) investigated the past Nigerian government's interventional efforts and attempts at addressing the hydra headed problems of unemployment in the country and their effectiveness at encouraging the sense entrepreneurship in the country with a view to facilitating job creation for the teaming Nigerians job seekers. The study relied on secondary data by way of existing literatures for the study while the results of the findings are presented with the aid of frequency tables. The finding from the study revealed that several intervention programmes introduced by successive governments in the country had failed to produce the expected results. Findings further indicated a plethora of bottlenecks which are principally hinged on corruptions, bureaucratic bottleneck vis-a-vis inconsistencies in government policies, political instability and lack of entrepreneurial skill 
by majority of unemployed Nigerians. The study recommended combined hard work on the part of the government to the development of entrepreneurship by providing an enabling environment and infrastructures coupled with the introduction of relevant entrepreneurial educational programmes in all institutions of learning be tailored towards development of entrepreneurial skills while start up loans should be made available without interests.

\section{Methodology and Data}

The estimation method that will be applied for this research study is the Dynamic ordinary least squares (DOLS) whereas Fully Modified Ordinary Least Squares (FMOLS) and Canonical Co-integration Regression (CCR) will serve as robustness checks. The method was selected based on the small sample size of the observation i.e. from 1991-2017 and it is applicable to estimating I(0) and I(1) variables or combination of the two since the dependent variable is integrated of order I(1). Dynamic Ordinary least Squares (DOLS) has advantages over the ordinary least squares that includes ability to eliminate endogeneity problem, ability to correct autocorrelation problem, ability to eliminate simultaneity bias and lastly ability to tackle small sample bias. Unemployment data is measured as the percentage of total labour force (modeled ILO estimate), Population is measured as the total population, GDP per capita is measured in current US\$, Foreign direct investment is measured as the net inflow (Bop, current US\$), inflation rate is measured in terms of consumer price index (annual \%) and foreign exchange rate which is measured in terms of official exchange rate (LCU per US\%, period average). All the variables for this study were extracted from World development indicators for period of 1991 to 2017 and were also converted into natural log forms.

\section{Model Specification}

The model is based on the previous studies that define unemployment as a function of total population (Gideon, 2015), that study the impact of population growth on unemployment while other studies have seen gross domestic product as being influenced by unemployment (Imoisi, 2017).

$\mathrm{UNEM}=\mathrm{F}$ (POP, CPI, GDPC, REXC, FDI)

The Dynamic Ordinary least Squares (DOLS) model is given below:

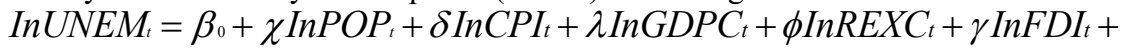

$\sum_{j=0}^{k} \Delta \chi_{i} \operatorname{InPOP}_{t+K}+\sum_{j=0}^{n} \Delta \delta_{i} \operatorname{In} C P I_{t+n}+\sum_{j=0}^{m} \Delta \lambda_{i} \operatorname{In} G D P C_{t+m}+\sum_{j=0}^{p} \Delta \phi_{i} \operatorname{In} R E X C_{t+p}+\sum_{j=0}^{q} \Delta \gamma_{i} \operatorname{In} F D I_{t+q}+\mu_{t}$

(2)

Where:

$\beta_{0}$; is the intercept parameter, $\beta_{1}-\beta_{5}$; are the coefficients of the independent variables, ln; Natural log, $\sum$; summation, $\mathrm{UNEM}_{\mathrm{t}}$; Unemployment, $\mathrm{POP}_{\mathrm{t}}$; Total Population, $\mathrm{CPI}_{\mathrm{t}}$; Consumer price index, GDPC $\mathrm{C}_{\mathrm{t}}$; Gross Domestic Product per capita, $\mathrm{REXC}_{\mathrm{t}}$; Foreign exchange rate, $\mathrm{FDI}_{\mathrm{t}}$; Foreign Direct Investment, $\mathrm{t}$; Time series (1991-2017), $\mu_{\mathrm{t}}$ and $\varepsilon_{\mathrm{t}}$; Stochastic Error terms or disturbances.

Robustness Check Using Fully Modified Ordinary Least Squares (FMOLS) and Canonical Co-integration Regression (CCR)

FMOLS and CCR have the power to deal with endogeneity problem, simultaneity bias and small sample bias. These estimators are good for robustness check of long-run estimates. FMOLS and CCR have been advanced by Philips and Moon (1999) and Park (1992) to address the problems of serial correlation and small sample bias attributed to OLS estimator. The estimators can also be applied to mix order of integrated variables in cointegration frame-work. Considering the strengths of these estimators, their results will be served as robustness checks to Dynamic Ordinary Least Squares (DOLS) result.

\section{Results and Discussions}

This section presents the results of the estimation and discusses the findings of the study. The descriptive statistics are presented in Table 1 with the correlation analysis of the variables used in the study. It is observed that from Table 1 the average Unemployment rate is approximately 4.073 while that of Exchange rate is 109.133. Population is $1.39 \mathrm{E}+08$. The average GDP per capita is approximately 1377.407 and Foreign Direct Investment is approximately 2.104 and the average value of Consumer price index is 69.733.All the variables are positively skewed as indicated by the positive skewed coefficients of all the variables. The study also tested for data normality using Jaque-Bera normality test. Three variables of the study such as Population, GDP per capita and consumer price index were found to be normally distributed since the P-values for Jarque-Bera test were greater than 0.05 for the variables. While two other variables which are Unemployment and Exchange rate were not normally distributed as indicated by their P-values of less than 0.05 . Using correlation analysis, all the variables are in logarithm form. The highest approximated value of correlation between consumer price index and total population 
which is 0.957 , the lowest approximated value of correlation is between foreign direct investment and Unemployment which is -0.522 and all the independent variables shows positive correlation with the dependent variable except foreign direct investment which shows negative correlation with the dependent variable.

Table 1: Descriptive Statistics and Correlation Results.

\begin{tabular}{|c|c|c|c|c|c|c|}
\hline & UNEM & REXC & POP & GDPC & FDI & CPI \\
\hline Mean & 4.073 & 109.133 & $1.39 \mathrm{E}+08$ & 1377.407 & 2.104 & 69.733 \\
\hline Median & 3.951 & 100.000 & $1.35 \mathrm{E}+08$ & 1007.874 & 1.911 & 52.556 \\
\hline Maximum & 6.237 & 275.294 & $1.91 \mathrm{E}+08$ & 3222.694 & 5.790 & 214.232 \\
\hline Minimum & 3.424 & 50.168 & 97667632 & 270.224 & 0.634 & 2.752 \\
\hline Skewness & 2.164 & 1.800 & 0.278 & 0.437 & 1.676 & 0.866 \\
\hline Kurtosis & 6.821 & 5.667 & 1.877 & 1.694 & 6.103 & 2.784 \\
\hline Jarque-Bera & $37.514(0.000)$ & $22.587(0.000)$ & $1.766(0.413)$ & $2.780(0.249)$ & $23.476(0.000)$ & $3.434(0.179)$ \\
\hline Observation & 27 & 27 & 27 & 27 & 27 & 27 \\
\hline $\operatorname{lnUNEM_{t}}$ & 1.000 & & & & & \\
\hline $\ln \mathrm{REXC}_{\mathrm{t}}$ & 0.166 & 1.000 & & & & \\
\hline $\ln \mathrm{POP}_{\mathrm{t}}$ & 0.483 & 0.123 & 1.000 & & & \\
\hline $\operatorname{lnGDPC} C_{t}$ & 0.213 & 0.064 & 0.939 & 1.000 & & \\
\hline $\operatorname{lnFDI} I_{t}$ & -0.522 & 0.000 & -0.631 & -0.589 & 1.000 & \\
\hline $\operatorname{lnCPI}{ }_{t}$ & 0.435 & 0.263 & 0.957 & 0.872 & -0.535 & 1.000 \\
\hline
\end{tabular}

Sources: EViews 9; Note: Values in parentheses are the P-values.

To examine the property of the data before conducting the estimation of the log-run model, the following are required. In the first step, we examine the non-stationarity or integration properties of the time series, using the widely used augmented Dickey-Fuller (ADF) and Philip-Perron (PP) unit root tests, in the second step, given that the variables are non-stationary. Table 2 a presents the testing of the unit root results; Unemployment is stationary at $5 \%$ level of significance after first differencing. Whereas exchange rate, total population, GDP per capita and Foreign direct investment were stationary at $1 \%$ level of significance after first differencing. And only consumer price index is stationary at level value and also at $1 \%$ level of significance. Unemployment in Philip Perron unit root test is also stationary at $10 \%$ level of significance after first differencing. Exchange rate, GDP per capita and FDI were also stationary after first difference at various levels of significance. Consumer price index still maintained the same result as shown in the ADF test. Therefore, since there is a mixed of order of integration of the variables, one variable is $\mathrm{I}(0)$ and others are purely $\mathrm{I}(1)$ then Dynamic Ordinary Least Squares is efficient to handle the long-run analysis.

Table 2a: augmented Dickey Fuller Unit Root Test Result

\begin{tabular}{|c|c|c|c|c|c|}
\hline \multicolumn{3}{|c|}{ Level Values } & \multicolumn{2}{|c|}{ First Difference } & \multirow[b]{2}{*}{$\begin{array}{c}\text { Order of } \\
\text { Integration }\end{array}$} \\
\hline Variables & Constant & $\begin{array}{l}\text { Constant } \\
\text { \& Trend }\end{array}$ & Constant & $\begin{array}{l}\text { Constant } \\
\text { \& Trend } \\
\end{array}$ & \\
\hline $\ln \mathrm{UNEM}_{\mathrm{t}}$ & $-2.733^{*}(0.082)$ & $-2.795(0.211)$ & $-3.331^{* *}(0.024)$ & $-3.567^{*}(0.055)$ & $\mathrm{I}(1)$ \\
\hline $\operatorname{lnREXC_{t}}$ & $-2.355(0.163)$ & $-2.256(0.441)$ & $-4.356^{* * *}(0.002)$ & $-6.124^{* * *}(0.000)$ & I (1) \\
\hline $\ln \mathrm{POP}_{\mathrm{t}}$ & $-0.661(0.838)$ & $-3.135(0.120)$ & $-4.323^{* * *}(0.002)$ & $-3.227(0.104)$ & I (1) \\
\hline $\operatorname{lnCPI} I_{t}$ & $-5.492^{* * *}(0.000)$ & $5.523^{* * *}(0.000)$ & ------------- & ----------------- & $\mathrm{I}(0)$ \\
\hline $\operatorname{lnGDPC} C_{t}$ & $-0.641(0.844)$ & $-1.653(0.742)$ & $-3.838^{* * *}(0.007)$ & $-3.754^{* *}(0.036)$ & I (1) \\
\hline $\operatorname{lnFDI} I_{t}$ & $-1.898(0.327)$ & $-3.424^{*}(0.069)$ & $-5.705^{* * *}(0.000)$ & $-5.703^{* * *}(0.000)$ & $\mathrm{I}(1)$ \\
\hline \multicolumn{6}{|c|}{ Philip Perron Unit Root Test Result (PP). } \\
\hline Variables & Constant & $\begin{array}{l}\text { Constant } \\
\text { \& Trend }\end{array}$ & Constant & $\begin{array}{l}\text { Constant } \\
\text { \& Trend }\end{array}$ & $\begin{array}{l}\text { Order of } \\
\text { Integration }\end{array}$ \\
\hline $\operatorname{lnUNEM}_{\mathrm{t}}$ & $-0.224(0.923)$ & $-0.519(0.975)$ & $-2.699^{*}(0.088)$ & $-2.824(0.202)$ & $\mathrm{I}(1)$ \\
\hline $\operatorname{lnREXC_{t}}$ & $-2.355(0.163)$ & $-2.256(0.441)$ & $-4.356^{* *}(0.002)$ & $-4.356^{* *}(0.010)$ & I ( 1$)$ \\
\hline $\operatorname{lnPOP}{ }_{t}$ & $5.370(1.000)$ & $-0.730(0.959)$ & $-4.323^{* * *}(0.002)$ & $-3.227(0.104)$ & I ( 1$)$ \\
\hline $\operatorname{lnCPI} I_{t}$ & $-5.492^{* * *}(0.000)$ & $5.523^{* * *}(0.000)$ & ----------------- & ---------------- & $\mathrm{I}(0)$ \\
\hline $\operatorname{lnGDPC} c_{t}$ & $-0.695(0.831)$ & $-2.020(0.563)$ & $-3.838^{* * *}(0.007)$ & $-3.697^{* *}(0.041)$ & I (1) \\
\hline $\operatorname{lnFDI} I_{t}$ & $-1.898(0.327)$ & $-3.424 *(0.069)$ & $-6.188^{* * *}(0.000)$ & $-6.070^{* * *}(0.000)$ & $\mathrm{I}(1)$ \\
\hline
\end{tabular}

Sources: EViews 9; Note: Values in parentheses are the P-values and $* * *, * * \& *$ represents statistically significant at $1 \%, 5 \%$ \& $10 \%$ levels.

But coming down to Kwiatkowski Philips-Schmidt-Shin unit root test result (KPSS) all the variables which includes unemployment, total population, exchange rate, consumer price index, GDP per capita and foreign direct investment are stationary at level values and at 1 percent significance level. And this KPSS unit root test results contradict the results of the ADF and PP tests shown above were only consumer price index is stationary at level while all other variables were stationary at first difference. 
Table 2b: Kwiatkowski Philips-Schmidt-Shin Unit Root Test Result (KPSS).

\begin{tabular}{|c|c|c|c|c|c|}
\hline \multicolumn{3}{|c|}{ Level Values } & \multicolumn{2}{|c|}{ First Difference } & \\
\hline Variables & Constant & $\begin{array}{l}\text { Constant } \\
\text { \& Trend }\end{array}$ & Constant & $\begin{array}{l}\text { Constant } \\
\text { \& Trend }\end{array}$ & $\begin{array}{c}\text { Order of } \\
\text { Integration }\end{array}$ \\
\hline $\ln \mathrm{NNEM}_{\mathrm{t}}$ & $0.283^{* * *}(0.739)$ & $0.131^{* * *}(0.216)$ & ----------------- & --------------- & I (0) \\
\hline $\operatorname{lnREXC_{t}}$ & $0.075^{* * *}(0.739)$ & $0.069^{* * *}(0.216)$ & ------------- & ------------- & I $(0)$ \\
\hline $\operatorname{lnPOP}_{t}$ & $0.784(0.739)$ & $0.204^{* * *}(0.216)$ & ------------ & ----------- & I ( 0$)$ \\
\hline $\operatorname{lnCPI} I_{t}$ & $0.762(0.739)$ & $0.159^{* * *}(0.216)$ & ---------------- & ------------- & I $(0)$ \\
\hline $\operatorname{lnGDPC}_{\mathrm{t}}$ & $0.706^{* * *}(0.739)$ & $0.124^{* * *}(0.216)$ & -------------- & ------------- & I ( 0$)$ \\
\hline $\operatorname{lnFDI}_{t}$ & $0.439^{* * *}(0.739)$ & $0.093^{* * *}(0.216)$ & --------------- & ---------------- & I $(0)$ \\
\hline
\end{tabular}

Sources: EViews 9; Note: Values in parentheses are the Asymptotic Critical-values and *** represents statistically significant at $1 \%$ level.

\section{Optimum Lag Selection Criteria}

From the results of the unrestricted vector auto regressive optimum lag selection criteria in table 3 below, using Final Prediction Error (FPE), Sequential Modified LR test Statistic (each test at 5\% level), Akaike Information Criterion (AIC), Hannan-Quinncriteria (HQ) and Schwarz Information Criteria (SC) revealed that lag 2 should be selected. Therefore, the maximum lag to be used in this study is lag 2 . Hence, we lagged the variables 1 times in order not to lose the degree of freedom.

Table 3: Unrestricted VAR Optimum Lag Selection Criteria Result.

\begin{tabular}{lllllll}
\hline Lag & LogL & LR & FPE & AIC & SC & HQ \\
\hline 1 & 371.151 & NA & $3.19 \mathrm{e}-20$ & -27.929 & $-26.162^{\mathbf{k}}$ & -27.460 \\
2 & 425.101 & $53.950^{\mathbf{k}}$ & $1.21 \mathrm{e}-20^{\mathbf{k}}$ & $-29.425^{\mathbf{k}}$ & -25.890 & $-28.487^{\mathbf{k}}$ \\
\hline
\end{tabular}

Sources: EViews 9; Note: ${ }^{\mathbf{k}}$ represents the lags selected by different criteria's.

\section{Co-integration Test Result}

The Johansen Juselius test for co-integration using model with Trace statistics and model with Max-Eigen value confirm the existence of five co-integration equations in each of the models. Therefore, we conclude that there is a long-run relationship among the dependent and independent variables or that the variables moved together in the long-run. This finding is in line with the result of researchers such as Bhally et al. (2013), Banda et al. (2016), Ademola and Badiru, (2016),

Table 4: Johansen Juselius Test for Co-integration

\begin{tabular}{cccccc}
\hline $\begin{array}{c}\text { Hypothesized } \\
\text { No. of CE(s) }\end{array}$ & Eigenvalue & Trace Statistic & $\begin{array}{c}\mathbf{0 . 0 5} \\
\text { Critical Value }\end{array}$ & $\begin{array}{c}\text { Max-Eigen } \\
\text { Statistic }\end{array}$ & $\begin{array}{c}\mathbf{0 . 0 5} \\
\text { Critical Value }\end{array}$ \\
\hline $\mathrm{r}=0$ & 0.945 & $228.671^{* * *}(0.000)$ & 95.753 & $72.513^{* * *}(0.000)$ & 40.077 \\
$\mathrm{r} \leq 1$ & 0.906 & $156.157^{* * *}(0.000)$ & 69.818 & $59.144^{* * *}(0.000)$ & 33.876 \\
$\mathrm{r} \leq 2$ & 0.813 & $97.012^{* * *}(0.000)$ & 47.856 & $41.982^{* * *}(0.000)$ & 27.584 \\
$\mathrm{r} \leq 3$ & 0.757 & $55.029^{* * *}(0.000)$ & 29.797 & $35.413^{* * *}(0.000)$ & 21.131 \\
$\mathrm{r} \leq 4$ & 0.539 & $19.616^{* * *}(0.011)$ & 15.494 & $19.412^{* * *}(0.007)$ & 14.264 \\
$\mathrm{r} \leq 5$ & 0.008 & $0.203(0.244)$ & 3.841 & $0.203(0.652)$ & 3.841 \\
\hline
\end{tabular}

Sources: EViews 9; Note: Values in parentheses are the P-values and ${ }^{* * *} \&^{* *}$ represents statistically significant at $1 \%$ \& $5 \%$ levels.

The log of Exchange rate is positive and significant to explain unemployment situation in Nigeria. Meaning that one naira increase in the value of exchange rate will bring about approximately 0.068 percent increase in the rate of unemployment in the country and in the long-run. This finding contradicts the findings of Banda et al. (2016). The natural log of total population is also positive and significant to explained unemployment in Nigeria. This means that 1 percent increase in total population will lead to an increase in the stock of unemployment by approximately 2.577 percent in the long-run from the model. This also confirmed the achievement of the main objective of the research study and is in line with the work of Bhally et al. (2013), but contradicts the result of Gideon, (2015). The natural log of consumer price index is also significant to explain unemployment in Nigeria. The consumer price index impacted negatively on unemployment meaning that percentage increase in the prices of products will bring about approximately -0.154 decrease in the level of unemployment in the long-run from the model. This is in conformity with the result of Bhally et al. (2013). The natural log of GDP per capita also has negative and significant relationship with unemployment in the long-run. This means that one percent change in GDP per capita will lead to a decrease in the rate of unemployment by approximately -0.411 in the current period from the model. The finding of John and Bright (2012) corroborate this result. The natural log of foreign direct investment also impacted negatively and significantly in explaining the dependent variable. Meaning that one dollar increase in the inflow of foreign direct investment into our country will reduce the rate of unemployment 
by approximately -0.068 in the long-run from the model result. The R-square value of 0.87 means that approximately $87 \%$ variation or changes in the dependent variable i.e. unemployment can be jointly explained by the independent variables such as total population, consumer price index, GDP per capita, exchange rate and foreign direct investment and only $13 \%$ variation in the dependent variable are explained by other factors that are not captured in the model or that are explained by the error term..

Table 5: Estimated Result for the impact of Population Growth on Unemployment using DOLS

\begin{tabular}{|c|c|c|c|c|}
\hline \multicolumn{5}{|c|}{ Dependent Variable = Unemployment } \\
\hline Variables & Coefficient & Std. Error & t-Statistic & Prob. \\
\hline $\operatorname{lnREXC_{t}}$ & $0.068^{*}$ & 0.038 & 1.767 & 0.091 \\
\hline $\ln \mathrm{POP}_{\mathrm{t}}$ & $2.577^{* * *}$ & 0.397 & 6.482 & 0.000 \\
\hline $\operatorname{lnCPI} I_{t}$ & $-0.154^{* * *}$ & 0.051 & -3.000 & 0.006 \\
\hline $\operatorname{lnGDPC} C_{t}$ & $-0.411^{* * *}$ & 0.051 & -8.003 & 0.000 \\
\hline $\operatorname{lnFDI} I_{t}$ & $-0.068^{*}$ & 0.037 & -1.827 & 0.081 \\
\hline $\mathrm{C}$ & $-43.712^{* * *}$ & 7.114 & -6.144 & 0.000 \\
\hline
\end{tabular}

R-squared

0.87

Sources: EViews 9; Note: ${ }^{* * *},{ }^{* *} \&{ }^{*}$ represents statistically significant at $1 \%, 5 \%$ \& $10 \%$ levels. DOLS; Dynamic Ordinary Least Squares.

As a robustness check to the Dynamic Ordinary least Squares result, we have employed fully Modified Ordinary Least squares (FMOLS) and Canonical Cointegration Regression (CCR), and their results are reported in table 6. Both FMOLS and CCR indicate that Real Exchange rate and total population have significant positive relationship with total Unemployment, whereas consumer price index, gross domestic per capita and foreign direct investment indicates a significant negative relationship with the rate of unemployment. This finding substantiates the long-run results of the Dynamic Ordinary least squares (DOLS), where Real exchange rate and total population are the only positive and significant determinant of Unemployment while Consumer price index, Gross domestic products and foreign direct investment have impacted negatively on total unemployment in Nigeria.

Table 6: FMOLS and CCR Test Results for Robustness Check.

\begin{tabular}{|c|c|c|c|c|}
\hline \multicolumn{5}{|c|}{ Depenedent Variable = Unemployment } \\
\hline \multirow[t]{2}{*}{ Variables } & Coefficient & Std. Error & Coefficient & Std. Error \\
\hline & $0.070^{*}$ & & $0.081^{* *}$ & \\
\hline \multirow{2}{*}{$\operatorname{lnREXC} C_{t}$} & $(1.987)$ & 0.035 & $(2.137)$ & 0.038 \\
\hline & $2.731^{* * *}$ & & $2.973^{* * *}$ & \\
\hline \multirow[t]{2}{*}{$\ln \mathrm{POP}_{\mathrm{t}}$} & $(7.554)$ & 0.361 & $(6.061)$ & 0.490 \\
\hline & $-0.144^{* *}$ & & $-0.179^{* * *}$ & \\
\hline \multirow[t]{2}{*}{$\operatorname{lnCPI} I_{t}$} & $(-2.697)$ & 0.053 & $(-3.350)$ & 0.053 \\
\hline & $-0.458^{* * *}$ & & $-0.474^{* * *}$ & \\
\hline \multirow[t]{2}{*}{$\operatorname{lnGDPC}_{\mathrm{t}}$} & $(-9.290)$ & 0.049 & $(-7.974)$ & 0.059 \\
\hline & $-0.066^{*}$ & & -0.069 & \\
\hline \multirow[t]{2}{*}{$\operatorname{lnFDI} I_{t}$} & $(-1.840)$ & 0.035 & $(-1.609)$ & 0.043 \\
\hline & $-46.324^{* * *}$ & & $-50.639^{* * *}$ & \\
\hline $\mathrm{C}$ & $(-7.152)$ & 6.476 & $(-5.786)$ & 8.751 \\
\hline
\end{tabular}

R-squared

Sources: EViews 9; Note: Values in parentheses are the t-statistic and ${ }^{* * *},{ }^{* *} \&{ }^{*}$ represents statistically significant at 1\%, 5\% \& 10\% levels. FMOLS; Fully Modify Ordinary Least Squares and CCR; Canonical Co-integrating Regression.

\section{Summary, Conclusion and Recommendation}

This empirical research tried to examine the relationship between unemployment and population growth in Nigeria, with annual data from 1991 to 2017 using Dynamic Ordinary Least Squares (DOLS). Fully Modify Ordinary Least Squares (FMOLS) and Canonical Co-integration Regression (CCR) testing techniques were used as robustness check in the process of estimating the model. The main results disclosed that there is a long-run association among the considered variables. The long-run estimated results revealed that unemployment is positively affected by total population and exchange rate. Population increase by 1 percent causes the rate of unemployment to increase by 2.577 at 1 percent level of significant, while the exchange rate increase by 1 percent causes unemployment to increase by 0.068 at 10 percent significant level. The consumer price index, GDP per capita and foreign direct investment have negative effect on unemployment in the long-run. Increase in consumer price index by 1percent, causes the unemployment to decrease by -0.154 at 1 percent level of significance in the long-run. If GDP per capita increase by 1 percent, it causes the rate of unemployment to decrease by -0.411 at 1 percent significance level in the long-run. If foreign direct investment increase by 1 percent causes the rate of 
unemployment to decrease by -0.068 at 10 percent level of significance in the long-run. The approximated RSquare value of 0.87 means that $87 \%$ changes in the dependent variable i.e. unemployment can be explained jointly by the independent variables in the long-run and only $13 \%$ changes in the dependent variable are explained by the stochastic error term.

The results were anticipated, the positive exchange rate which will depicts depreciation of the local currency is also in line with the theoretical basis that depreciation of the currency will produce inflation since the purchasing power of the domestic currency become less. Increase in population will in the same way cause an increase in the total supply of labour thereby causing excess supply over the demand for labour in the economy. Consumer price index, GDP per capita and foreign direct investment all have negative relationship with the unemployment meaning that these macroeconomics variables help to reduce the rate of unemployment in the long-run period. The results led to the recommendation that government should pursue measures that will help to reduce the growth rate of population in order to control the supply of labour and consequently led to the reduction in the rate of unemployment, also government should encourage industrialization policy and flow of foreign direct investment into the country in order to provides employment opportunities to the unemployed teaming population.

\section{References}

1. Adekola, P.O., Allen, A.A., Olawole-Isaac, A., Akanbi, M.A. \& Adewumi, O. (2016) Unemployment in Nigeria; A Challenge of Demographic Change?, International Journal of Scientific Research in Multidisciplinary Studies 2(5): 1-9. http// www.isroset.org

2. Ademola, A.S. \& Badiru, A. (2016): The Impact Unemployment and Inflation on Economic Growth in Nigeria (1981-2014), International Journal of Business and Economic Sciences applied Research (IJBERSAR), ISSN 2408-0101, 9(1):47-55. http://hdi.handle.net/10419/144673

3. Anuolam, M.O. \& Anuforo, E.E (2014) an Econometric Examination of Growth, Unemployment and Poverty in Nigeria, West Africa Journal of Industrial \& Academic Research 2(1):117-133.

4. Bhalli, M. N., Muhammad, S.M. \& Tahir, M.A (2013), Determinants of Unemployment: Empirical Evidences from Pakistan, Pakistan Economic and Social Review 51(2): 191-207.

5. Evans,O.(2011) Economic of Population Expansion in Nigeria. http://olaniyievans.blogspot.com/2011/06/economics-of-population-expansion-in.html

6. Gideon, H.E. (2016) Population Growth in Nigeria, Economic Development, Yola, Adamawa state of Nigeria

7. Handson, B., Hlanganipai, N. \& Fortune, H. (2016) “ The Impact of Economic Growth on Unemployment in South Africa: 1994-2012" Investment Management and financial Innovation 13(2): 246-255. DOI:10.21511/imfi.13 (2-1).2016.11

8. Ilegbinosa, I.A., Moses, O.L. \& Praise U.A. (2014) Population and its Impact on Level of Unemployment in the Least Developed Countries: An of the Nigerian economy. Arts \& Social Sciences journal 5(2): 2-7. DOI:10.4172/2151-6200.100081

9. Imoisi, A.I., Amba, E.A. \& Okon, I.M. (2017), "Unemployment Rate and Economic Growth in Nigeria: 19812016", International Journal of Development and Sustainability 6(7): 369-384. http// www.isdsnet.com/ijds

10. International Labour organization (2018), ILO Labour Force Estimations and Projections (LFEP) Key Trends: pages 1-7. http// www.ILOSTAT.com

11. Loku, A. \& Deda (2013) Unemployment in Relation of Growth Population, International Journal of Research in Social Sciences 2(2). www.ijsk.org/ijrss

12. Orumie, U.C. (2016) The Effect of Unemployment Rate and Population Growth Rate on Gross Domestic Poduct in Nigeria, International Journal of Applied Science and mathematics 3(1): 2394-2894.

13. Rosina, G. (2018) Avoiding Unemployment is not Enough, An Analysis of other forms of Labour Undernization, Spotlight on Work Statistics (ILOSTAT): 1-12. http://www.ilo.org/ilostat

14. Rosina, G. (2019) Labour market Access - a Persistent Challenge for Youth around the World, A Study Based on ILO's Global Estimates for Youth Labour Market Indicators, Spotlight on Work Statistic (ILOSTAT): 110. http://www.ilo.org/ilostat

15. Rosina, G. (2018) Paid Employment vs Vulnerable Employment, A Brief Study of Employment Patterns by Status in Employment, International Labour Organization (ILOSTAT), page 1-8. http://www.ilo.org/publications.

16. World Development Indicators at World Bank Data Base (2019). Retrieved 20 $0^{\text {th }}$ March, 2019 from: http://data.wordbank.org/indicators.

Author's Corner

MUSA, Kabiru Saidu: is a postgraduate student at the Department of Economics, Faculty of Social and Management Sciences, Bauchi State University, Gadau, Yuli Campus, Bauchi State of Nigeria.

MAIJAMA'A, Rabiu: is also a postgraduate student at the Department of Economics, Faculty of Social and Management Sciences, Bauchi State University, Gadau, Yuli Campus, Bauchi State of Nigeria and currently 
working with Nigeria National Petroleum Corporation (NNPC).

MOHAMMED, Nafisa: she is also a postgraduate student at the Department of Economics, Faculty of Social and Management Sciences, Bauchi State University, Gadau, Yuli Campus, Bauchi State of Nigeria and working with Central Bank of Nigeria (CBN) Gombe State Branch.

YAKUBU, Muktari: is also a postgraduate student at the Department of Economics, Faculty of Social and Management Sciences, Bauchi State University, Gadau, Yuli Campus, Bauchi State of Nigeria. 